\title{
VALUE ADDED CULTURED DAIRY PRODUCTS: CARROT YOGURT DEVELOPMENT AND OPTIMIZATION OF THE CHARACTERISTICS.
}

\section{DHANESH NADEEJAYA LIYANAGE}

Senior Lecturer, Department of Food Science and Technology, Wayamba University of Sri Lanka, Sri Lanka

ABSTRACT
Yogurt is one of the most demanded cultured dairy products rich in dairy nutrition. Attempts were made to develop a
novel yogurt combining the dairy nutrition and carrot. The carrot yogurt recipe preferred during sensory evaluation
consists of $65 \%$ fresh milk, $19.5 \%$ carrot pulp, $10 \%$ sugar, $5 \%$ skim milk powder and $0.5 \%$ gelatin. The optimum
potassium sorbate level for the carrot yogurt preservation is $0.1 \%$. Total acidity, pH value and, yeast and mould counts
of carrot yogurt were under the acceptable values for 4 weeks storage at refrigerated conditions $\left(4^{\circ}\right.$ C). One serving of
carrot yogurt ( $85 \mathrm{~g})$ provides $40 \%$ of vitamin A and $15 \%$ of calcium daily value requirements, which is higher than the
regular yogurt. Further, carrot yogurt supplies $0.32 \mathrm{~g}$ of dietary fibre per serving. Development of novel carrot yogurt
can be considered as a diversification attempt of cultured dairy products and it can be utilized to supply vegetable
nutrition in the form of a desert.
KEYWORDS: Carrot, Yogurt, Shelf life, Nutrition

Received: Oct 23, 2020; Accepted: Nov 13, 2020; Published: Dec 02, 2020; Paper Id.: IJASROCT20204

\subsection{INTRODUCTION}

Milk is composed of different amounts of water, fat, lactose, proteins and minerals depending on the species of mammal and further varies with the days of lactation, environmental conditions, genetics, physiological and nutrition conditions (Dunshea et al., 2019). Milk is the main source of saturated fat in human nutrition and it is a good source of macro minerals $\mathrm{Ca}, \mathrm{Mg}, \mathrm{P}$ and $\mathrm{K}$ as well as Micro minerals such as I, Se and Zn (Tăbăran et al., 2015). Dietary fibre is one of the nutrition least consumed by urban population, which is also lacked in dairy products (Alfieri et al., 1995). Global dairy milk consumption data clearly shows a trend of less consumption of liquid milk over the decades due to various reasons, one such cause is lactose intolerance. Part of the adult population lacks the ability of digestion of dairy sugar, which results less consumption of dairy milk among adult population, yet it is possible for them to consume cultured dairy products due to the conversion of lactose into lactic acid during the fermentation process happened in cultured dairy product production (Dekker et al., 2019).

Cultured dairy products had been made for centuries with the use of milk drawn from cows, buffalos, sheep, goat or horses with the addition of inoculums containing lactic acid bacteria. Bacterial inoculums convert the dairy sugar, lactose, to lactic acid which results properties in the products having higher shelf life, organoleptic properties and nutritional properties (De Santis, 2019). Cultured dairy products play a main role in diet in modern diets and variety of novel value added products are produced to cater the needs of consumers. Yogurt leads the cultured dairy products in most of the countries and it is one of the highly value added products among the cultured dairy products (Aryana and Olson, 2017). 
There are many different yogurt types such as set, stirred, frozen, drinking, strained (Greek), further they are diversified with many modifications by adding different flavours, different types of fruit, blending with other deserts (Bylund, 2003). Attempts were taken in this study to develop yogurt blended with vegetable nutrition, carrot, by incorporating the vegetable nutrition, yet maintaining the organoleptic properties of yogurt.

\subsection{METHODOLOGY}

Carrot yogurt was prepared using dairy milk, carrot pulp, sugar, skim milk, gelatin as ingredients, freeze dried bacterial starter culture as inoculums and potassium sorbate as preservative. Firstly, prepared carrot pulp was added with skimmed milk power and bacterial culture to develop a mother culture. Thereafter, boiled milk was added with sugar and gelatin and mixed to dissolve. When the temperature of milk mixture dropped to $45^{\circ} \mathrm{C}$, it was added with mother culture to prepare the yogurt mixture. The organoleptic features with different levels of ingredients were measured using sensory evaluations. Best recipe of the carrot yogurt was tested for shelf life with the addition of potassium sorbate as preservative. During the study all the yogurt samples kept under the refrigerated conditions $\left(4^{\circ} \mathrm{C}\right)$.

\subsubsection{Carrot Pulp Preparation}

Well cleaned carrot was taken after removing the vegetative parts and, steam cooked using a pressure cooker. When the carrot was cooked thoroughly, skin of the carrot and centre core of carrot were removed. Then the carrot flesh was pulped to have a smooth texture using a blender.

\subsubsection{Mother Culture Preparation}

Skimmed milk powder (75 g) and three levels of carrot pulp (200 g, $300 \mathrm{~g}$ and $400 \mathrm{~g}$ ) were mixed thoroughly to have different ratios. Mixtures were added and mixed with commercially available pure freeze dried lactic acid bacteria starter culture $(0.34 \mathrm{~g})$ and left for mother culture preparation at $45^{\circ} \mathrm{C}$ for 1 hour and 30 minutes.

\subsubsection{Yogurt Mixture Preparation}

Cow's milk $(1 \mathrm{~L})$ was boiled for 40 minutes at $85^{\circ} \mathrm{C}$ and added with well mixed sugar (three levels $100 \mathrm{~g} / \mathrm{L}, 150 \mathrm{~g} / \mathrm{L}$ and $200 \mathrm{~g} / \mathrm{L}$ ) and gelatin (three levels $4 \mathrm{~g} / \mathrm{L}, 6 \mathrm{~g} / \mathrm{L}$ and $8 \mathrm{~g} / \mathrm{L}$ ) mixture. When the temperature dropped to $45^{\circ} \mathrm{C}$, previously prepared mother culture was added and mixed well. Then mixture was added to yogurt cups having $85 \mathrm{~g}$ of total mixture and incubated for 2 hours at $45^{\circ} \mathrm{C}$.

\subsection{Sensory Evaluation}

Sensory tests were carried out to find out the optimum organoleptic characteristics such as sweetness, flavour and colour and texture. Further, separate sensory test was carried out to find out the consumer preference for novel carrot yogurt and regular yogurt (control). Each sensory test was conducted using 30 untrained panellists in Makandura premises, Wayamba University of Sri Lanka. Ranking test was used to evaluate the responses of the panellists.

\subsection{Shelf Life Evaluation}

In determining the shelf life of the carrot yogurt, chemical parameter analysis and microbial analysis were done.

\subsubsection{Chemical Analysis}

Moisture content determination, $\mathrm{pH}$ value of yogurt and titrable acidity of yogurt were done by oven drying method, by 
using $\mathrm{pH}$ meter method and, acid base titration method respectively.

\subsubsection{Microbial Analysis}

Yeast and mould count was done using pour plate method using potato dextrose agar as the medium.

\subsection{Statistical Analysis}

Data was statistically analysed using R studio software.

\subsection{RESULTS}

The recipe containing $300 \mathrm{~g} / \mathrm{L}$ carrot pulp was considered as the most preferred by the panellists. Composition of the most preferred carrot yogurt recipe is given in Table 1.

Table 1: Composition of Carrot Yogurt

\begin{tabular}{|l|l|}
\hline Ingredient & Amount \\
\hline Milk & $1(\mathrm{~L})$ \\
\hline Skim milk powder & $75(\mathrm{~g})$ \\
\hline Carrot pulp & $300(\mathrm{~g})$ \\
\hline Sugar & $150(\mathrm{~g})$ \\
\hline Gelatin & $8(\mathrm{~g})$ \\
\hline
\end{tabular}

The above recipe resulted 14 carrot yogurt servings having $85 \mathrm{~g}$ per serving. Nutrition analysis of carrot yogurt was done using the Food Processor SQL software and it revealed that one serving provides about $110 \mathrm{kcal}$ per serving. Further, one serving of carrot yogurt supplies $40 \%$ vitamin A and 15\% calcium daily requirement values. Detailed nutrition composition of carrot yogurt is given in Table 2 .

Table 2: Detailed Nutrition of Carrot Yogurt per Serving (85 g)

\begin{tabular}{|c|c|c|c|c|c|}
\hline Basic Components & $\begin{array}{l}\text { Value per } \\
\text { Serving }\end{array}$ & Vitamins & $\begin{array}{l}\text { Value per } \\
\text { Serving }\end{array}$ & Minerals & $\begin{array}{c}\text { Value per } \\
\text { Serving }\end{array}$ \\
\hline Gram Weight (g) & 85 & Vitamin A - IU (IU) & 1940.68 & Calcium (mg) & 162.03 \\
\hline Calories (kcal) & 111 & Vitamin A - RAE (RAE) & 124.11 & Chromium (mcg) & 0.05 \\
\hline Cal. from Fat (kcal) & 21.2 & Carotenoid RE (RE) & 183.92 & Copper (mg) & 0.03 \\
\hline Cal. from SatFat (kcal) & 12.02 & Retinol RE (RE) & 32.14 & Fluoride $(\mathrm{mg})$ & 0.01 \\
\hline Protein $(\mathrm{g})$ & 4.96 & Beta-Carotene (mcg) & 897.71 & Iron $(\mathrm{mg})$ & 0.1 \\
\hline Carbohydrates (g) & 17.9 & Vitamin B1 (mg) & 0.07 & Magnesium (mg) & 17.02 \\
\hline Dietary Fibre $(\mathrm{g})$ & 0.32 & Vitamin B2 (mg) & 0.25 & Manganese (mg) & 0.02 \\
\hline Soluble Fibre $(\mathrm{g})$ & 0 & Vitamin B3 (mg) & 0.19 & Phosphorus (mg) & 122.9 \\
\hline Total Sugars $(\mathrm{g})$ & 17.18 & Vit. B3 - Niacin Equ (mg) & 0.65 & Potassium (mg) & 215.66 \\
\hline Monosaccharides (g) & 0.08 & Vitamin B6 (mg) & 0.07 & Selenium $(\mathrm{mcg})$ & 3.01 \\
\hline Disaccharides $(\mathrm{g})$ & 17.1 & Vitamin B12 (mcg) & 0.56 & Sodium $(\mathrm{mg})$ & 70.3 \\
\hline Other Carbs (g) & 0.4 & Biotin (mcg) & 0.54 & Zinc (mg) & 0.52 \\
\hline Fat $(\mathrm{g})$ & 2.36 & Vitamin C (mg) & 1.39 & Poly Fats & \\
\hline Saturated Fat (g) & 1.34 & Vitamin D - IU (IU) & 1.43 & Omega 3 FA (g) & 0.05 \\
\hline Mono Fat (g) & 0.58 & Vit. E - Alpha-Toco (mg) & 0.16 & Omega 6 FA (g) & 0.1 \\
\hline Poly Fat $(\mathrm{g})$ & 0.15 & Folate $(\mathrm{mcg})$ & 7.92 & Other Nutrients & \\
\hline Trans Fatty Acid (g) & 0 & Folate, DFE (mcg) & 7.92 & Alcohol (g) & 0 \\
\hline Cholesterol (mg) & 7.14 & Vitamin K (mcg) & 1.68 & Caffeine (mg) & 0 \\
\hline Water $(\mathrm{g})$ & 72.86 & Pantothenic Acid (mg) & 0.46 & Choline (mg) & 11.38 \\
\hline
\end{tabular}




\subsection{Organoleptic Properties}

Colour and flavour of the yogurt was resulted by added carrot pulp and out of the 30 non-trained panellists, 18 and 16 panellists preferred the colour and flavour of carrot yogurt added with $30 \%$ pulp over the other pulp ratios. Sweetness of carrot yogurt added with $150 \mathrm{~g} / \mathrm{L}$ was preferred by 16 out of the 30 non-trained panellists. Texture of carrot yogurt was mainly resulted by added gelatin and 22 out of the 30 non-trained panellists preferred the texture of carrot yogurt made out of gelatin added with $8 \mathrm{~g} / \mathrm{L}$ ratio.

\subsection{Moisture Content of Carrot Yogurt Recipes}

Moisture contents of all carrot yogurt samples added with different potassium sorbate levels $(0.0 \%, 0.05 \%, 0.075 \%, 0.1 \%)$ did not vary significantly $(\mathrm{P}>0.05)$.

\subsection{Variation of pH Value of Carrot Yogurt}

Carrot yogurt added with different levels of potassium sorbate as preservative were tested for the variation of $\mathrm{pH}$ value for 32 days and lowest $\mathrm{pH}$ value drop was observed in carrot yogurt added with $0.1 \%$ and highest $\mathrm{pH}$ drop was observed in control ( $0.0 \%$ potassium sorbate) sample. Control sample had significantly lower $(\mathrm{P}<0.05)$ overall $\mathrm{pH}$ drop compared to all samples added with potassium sorbate and also significantly lower overall $\mathrm{pH}$ drop was observed in samples treated with $0.1 \%$ potassium sorbate compared to $0.05 \%$ treated samples. Variation of the $\mathrm{pH}$ value of carrot yogurt over time is given in Figure 1.

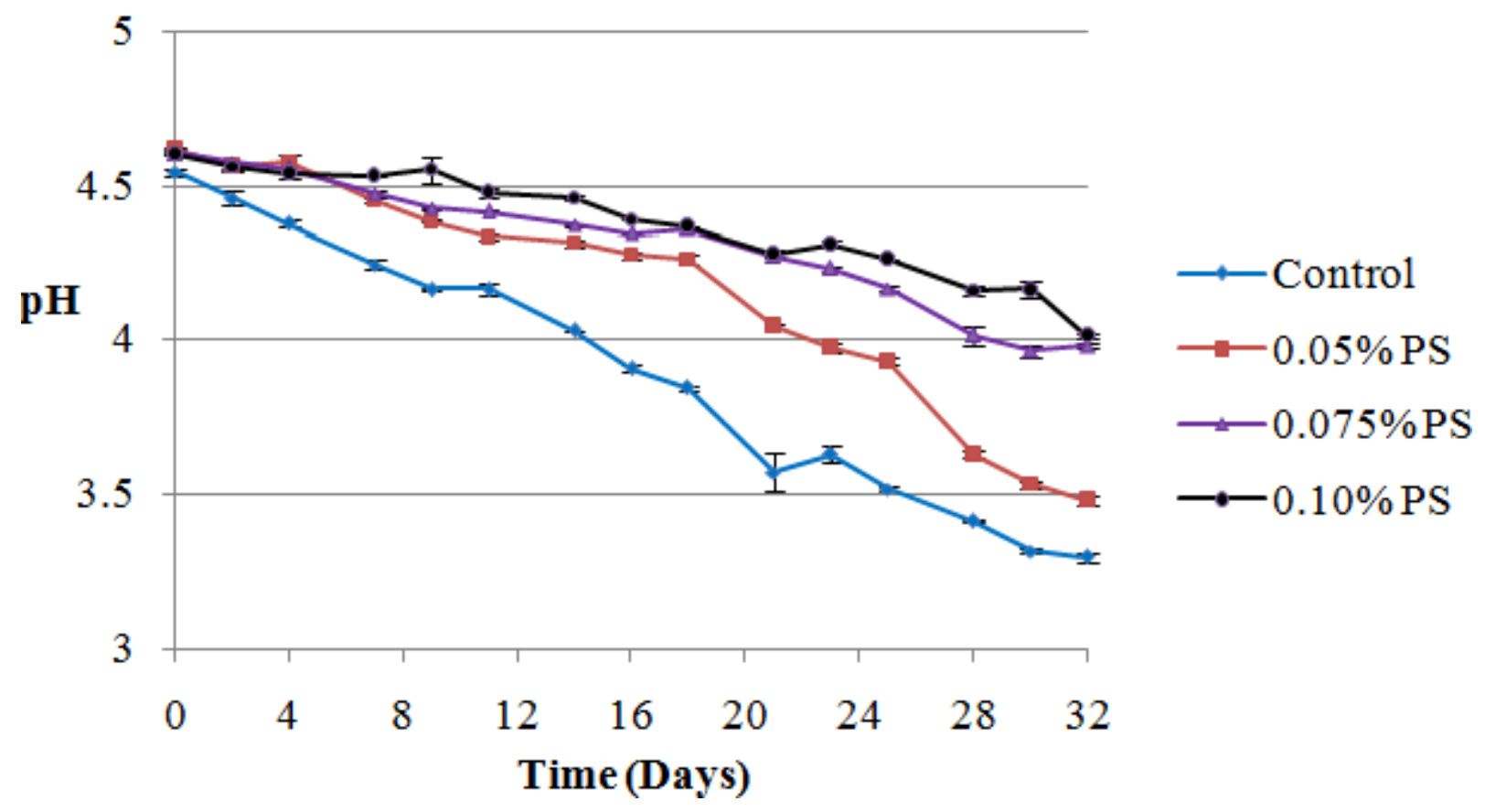

Figure 1: Variation of pH value of Carrot Yogurt Samples Added with Different Levels of Potassium Sorbate

\subsection{Variation of Titrable Acidity of Carrot Yogurt}

Titrable acidity of yogurt was tested and represented as lactic acid in this study. Highest titrable acidities $(\mathrm{P}<0.05)$ were observed in the control samples compared to samples treated with potassium sorbate. Similar titrable acidity levels were observed in carrot yogurt samples treated with potassium sorbate. Variation of the titrable acidity of carrot yogurt over time is given in Figure 2. 


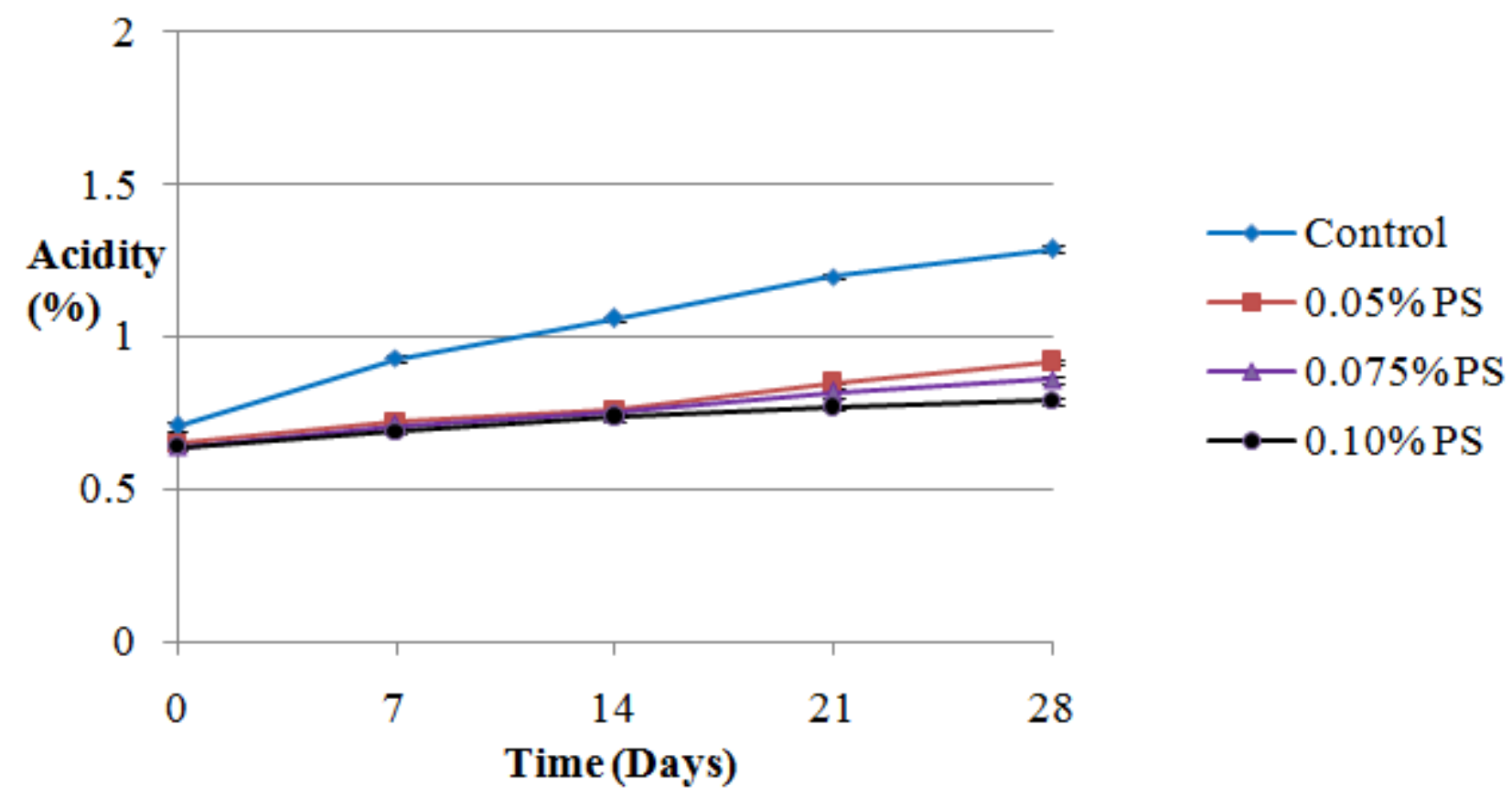

Figure 2: Variation of Acidity value of Carrot Yogurt Samples Added with Different Levels of Potassium Sorbate

\subsection{Variation of Yeast and Mould Counts of Carrot Yogurt}

Control samples had significantly higher $(\mathrm{P}<0.05)$ overall yeast and mouldvalues compared to $0.075 \%$ and $0.1 \%$ potassium sorbate treated samples, yet no overall yeast and mould count differences $(\mathrm{P}>0.05)$ were observed among the potassium sorbate treated samples. Variation of the yeast and mould counts of carrot yogurt over time is given in Figure 3.

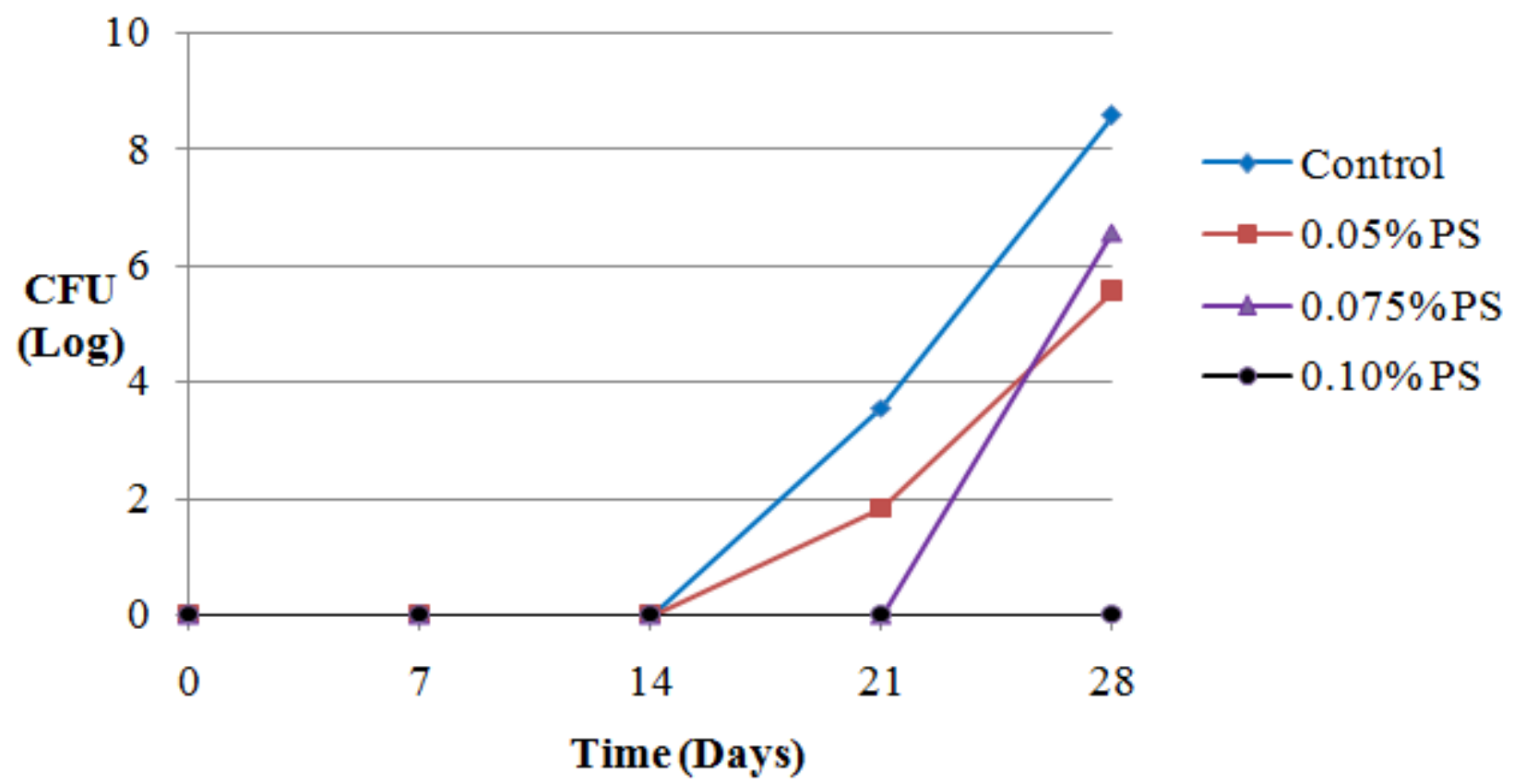

Figure 3: Variation of Yeast of Mould Count of Carrot Yogurt Samples added with Different Levels of Potassium Sorbate 


\subsection{DISCUSSION}

Yogurt is a good source of nutrition and yet lacks dietary fibre. Carrot yogurt was developed aiming the combination of dairy nutrition with vegetable nutrition. In comparing the carrot yogurt with regular yogurt, carrot yogurt serving supplies very high amount of vitamin A requirement (40\% of daily value) compared to regular (USDA, 2019). Further, it provides $0.32 \mathrm{~g}$ of dietary fibre as it contains carrot. Modern day kids consumes less vegetables, therefore, carrot yogurt can be utilized to supply vegetable nutrition as kids prefer to consume deserts such as yogurt. High value of vitamin A precursor (beta carotene) available in carrot yogurt acts as an anti-oxidant (Green and Fascetti, 2016), provides nutrition essential for vision, slows down cognitive slow decline (Carter, 2011) and, helps to develop a lighter skin tone at high level of consumption.

Yogurt added with no preservatives generally has a 2 week shelf life at refrigerated conditions $\left(4^{\circ} \mathrm{C}\right)$ and it has a 4 week shelf life with the use of preservatives. Yogurt is a fermented product made by lactic acid bacteria; therefore, it is preserved from other bacteria by the naturally produced lactic acid. Since the yogurt is an acidic food, it is normally spoiled by yeast and mould (Buehler et al., 2018). Further, excessive microbial action in yogurt results higher acidity in yogurt and yogurt is not suitable for consumption when the total acidity exceeds $1 \%$. Potassium sorbate is most commonly used preservative in yogurt preservation and generally allowed level in yogurt is 0.1\% (Codex Alimentarius, 2003). With compared to acidity level and yeast and mould counts of carrot yogurt, it can be preserved for 4 weeks under the refrigerated condition by adding $0.1 \%$ potassium sorbate as the preservative.

\subsection{CONCLUSIONS}

Carrot yogurt can be made by adding $30 \%$ of carrot pulp without changing the organoleptic characteristics. In getting preferred textural characteristics of carrot yogurt, required gelatin level is $8 \mathrm{~g} / \mathrm{L}$. Carrot yogurt can have a 4 weeks shelf life without changing the organoleptic, chemical and microbial properties by adding $0.1 \%$ potassium sorbate as preservative.

\section{REFERENCES}

1. Dunshea, F., Walker, G., Williams, R. and Doyle, P. (2019). Mineral and Citrate Concentrations in Milk are Affected bySeasons, Stage of Lactation and Management practices. Agriculture. 9(2), 25. https://doi.org/10.3390/agriculture9020025

2. Tăbăran, A., Balteanu, V.A., Gal, E., Pusta, D., Mihaiu, R., Dan, S.D., Tăbăran, A.F. and Mihaiu, M. (2015). Influence of DGAT1 K232A Polymorphism on Milk Fat Percentage and Fatty Acid Profiles in Romanian Holstein Cattle. Animal Biotechnology. 26(2), 105-111.

3. Alfieri, M. A., Pomerleau, J., Grace,D. M., and Anderson, L. (1995). Fibre Intake of Normal Weight, Moderately Obese and Severely Obese Subjects. Obesity Research. 3, 541-547.

4. OFFIA OLUA, B. I., QC ELUWA, and C. ABUAJAH. "Incorporation of Papain into Ice Cream: Impact on Pawpaw (Carica Papaya) Ice Cream Quality." IASET: International Journal of Biology, Biotechnology and Food Science (IASET: IJBBFS) 1.1: 7-22.

5. Aryana, K.J. and Olson, D.W. (2017). A 100-Year Review: Yogurt and Other Cultured Dairy Products. Journal of Dairy Science. 100, 9987-10013.

6. Dekker, P.J.T., Koenders, D. and Bruins, M.J. (2019).Lactose-Free Dairy Products: Market Developments, Production, Nutrition and Health Benefits. Nutrients. 11(3):551. doi: 10.3390/nu11030551.

7. De Santis, D., Giacinti, G., Chemello, G. and Frangipane M.T. (2019).Improvement of the Sensory Characteristics of Goat Milk Yogurt. Journal of Food Science, 84(8):2289-2296. 
8. Patel, MEHUL D., et al. "Adaptive physiological and biochemical responses of dairy animals to heat stress: a review." International Journal of Applied and Natural Sciences 5.1 (2016): 107-116.

9. Bylund, G. (2003). Dairy Processing Handbook. Tetra Pak Processing Systems AB.

10. USDA (2019). FoodData Central. https://fdc.nal.usda.gov/fdc-app.html\#/food-details/384435/nutrients Accessed on 10 November 2020

11. Green, A.S. and Fascetti A.J. (2016). Meeting the Vitamin A Requirement: The Efficacy and Importance of $\beta$-Carotene in Animal Species. The ScientificWorldJournal. doi:10.1155/2016/7393620

12. Carter, C.J. (2011).The Fox and the Rabbits-Environmental Variables and Population Genetics (1) Replication Problems in Association Studies and the Untapped Power of GWAS (2) Vitamin A Deficiency, Herpes Simplex Reactivation and Other Causes of Alzheimer's Disease. ISRN Neurology. doi: 10.5402/2011/394678

13. Shah, Mehul K., Chetan B. Bhatt, and JAIMIN B. DAVE. "NIR spectroscopy: Technology ready for food industries applications." Int. J. Appl. Nat. Sci. IJANS 5.1 (2016): 129-138.

14. Buehler, A.J., Martin, N.H., Boor, K.J. and Wiedmann, M. (2018). Evaluation of Biopreservatives in Greek Yogurt to Inhibit Yeast and Mold Spoilage and Development of a Yogurt Spoilage Predictive Model. Journal of Dairy Science. 101(12):1075910774.

15. SENTHILKUMAR, S., et al. "CUSTOMERS COGNIZANCE FACTORS INFLUENCING PURCHASING DECISION OF DESIGNATED DAIRY PRODUCTS." International Journal of Mechanical and Production Engineering Research and Development (IJMPERD) ISSN (P): 2249-6890; ISSN (E): 2249-8001 Vol. 10, Issue 3, Jun 2020, 3557-3568

16. Codex Alimentarius (2003). Codex Standards for Fermented Milk, Codex Stan 243-2003.http://www.fao.org/fao-whocodexalimentarius/en/ Accessed on 06 November 2020. 
